\title{
Ohrarehun ja ohravalkuaisrehun käyttö lihanautojen ruokinnassa.
}

\author{
Arto Huuskonen ${ }^{1)}$, Sirpa Lunki $^{1)}$ ja Asko Rantanen ${ }^{2)}$ \\ ${ }^{1)}$ MTT, Pohjois-Pohjanmaan tutkimusasema,92400 Ruukki, etunimi.sukunimi@mtt.fi \\ 2) Altia Oyj, Koskenkorvan tehdas, 61330 Koskenkorva, asko.rantanen@altiacorporation.com
}

\section{Tiivistelmä}

Elintarvikkeita valmistettaessa syntyy monia sivutuotteita, jotka soveltuvat käytettäväksi märehtijöiden ruokinnassa. Elintarviketeollisuus ja kotieläintalous muodostavat kokonaisuuden, jossa osapuolet täydentävät hyvin toisiaan. Ilman kotieläintuotantoa monilla elintarviketeollisuuden sivutuotteilla ei olisi taloudellista käyttöä. Kierrättämällä sivutuotteita kotieläinten kautta voidaan elintarviketeollisuudelle tuottaa raaka-ainetta kohtuuhintaisilla rehuilla ja samalla pienentää sivutuotteiden aiheuttamia jätehuoltokustannuksia, jotka nostavat elintarvikkeiden hintaa.

Tässä raportoidun tutkimuksen tarkoituksena oli määrittää alkoholiteollisuuden sivutuotteena syntyvien ohrarehun ja ohravalkuaisrehun tuotantovaikutus kasvavien lihanautojen ruokinnassa. Ruokintakokeella (32 maitorotuista lihanautaa) tutkittiin ohrarehun (energiarehu) ja ohravalkuaisrehun (valkuaisrehu) vaikutuksia rehun syöntiin, sonnien kasvuun sekä teurastuloksiin.

Koeruokinnat ( 2 x 2 faktoriaalinen koe) erosivat toisistaan väkirehu- ja valkuaisruokinnan koostumuksien osalta. Puolet koe-eläimistä sai väkirehuna pelkkää ohraa ja toinen puoli väkirehuseosta, jossa puolet ohran kuiva-aineesta oli korvattu ohrarehulla. Molemmilla väkirehuruokinnoilla oli kaksi erilaista valkuaisruokintaa: 1) valkuaislisänä rypsirouhetta (500 g/eläin/pv) ja 2) valkuaislisänä ohravalkuaisrehua (2,5 kg/eläin/pv). Väkirehun tavoiteltu osuus oli 55 \% päivittäisestä kuiva-aineen syönnistä kaikilla neljällä ruokinnalla. Sonnit ruokittiin seosrehuruokinnalla.

Ohrarehun käyttö väkirehussa lisäsi sonnien seosrehun syöntiä ( $<<0.01)$. Lisääntynyt rehun syönti ei kuitenkaan lisännyt ravintoaineiden saantia merkitsevästi eikä siten vaikuttanut kasvutuloksiin. Tämä johtuu siitä, että ohrarehun sulavuus ja energia-arvo ovat ohraa hieman heikompia.

Ohrarehulla on mahdollista korvata ainakin puolet kasvavan lihanaudan väkirehuannoksesta ilman, että se vaikuttaisi negatiivisesti tuotokseen. Naudanlihantuottajan kannalta ohrarehun käyttö ruokinnassa muodostuu taloudellisesti järkeväksi, jos sen hinta suhteessa tuotantovaikutukseen on edullisempi kuin muiden käytettävissä olevien väkirehujen. Tärkkelyspitoisen väkirehun osittainen korvaaminen kuitupitoisella ohrarehulla on erityisen perusteltua suurilla väkirehumäärillä ruokittaessa, koska kuitupitoinen väkirehu fermentoituu pötsissä viljan tärkkelystä hitaammin. Tämä puolestaan vähentää korkeisiin väkirehumääriin liittyviä ruokinnallisia riskejä.

Rypsin korvaaminen ohravalkuaisrehulla ei vaikuttanut tilastollisesti merkitsevästi lihanautojen rehun syöntiin tai kasvutuloksiin. Ohravalkuaisrehudieetillä raakavalkuaisen sulavuus oli kuitenkin heikompi kuin rypsiä sisältäneellä ruokinnalla $(\mathrm{p}<0.001)$. Ohravalkuaisrehua saaneet sonnit rasvoittuivat voimakkaammin kuin rypsillä ruokitut eläimet $(\mathrm{p}<0.05)$, mikä heikensi ohravalkuaisrehulla ruokittujen sonnien taloudellista tulosta.

Asiasanat: naudanlihantuotanto, lihanaudat, ruokinta, rehut, ohrarehu, ohravalkuaisrehu 


\section{Johdanto}

Elintarvikkeita valmistettaessa syntyy monia sivutuotteita, jotka soveltuvat käytettäväksi märehtijöiden ruokinnassa. Elintarviketeollisuus ja kotieläintalous muodostavat kokonaisuuden, jossa osapuolet täydentävät hyvin toisiaan. Ilman kotieläintuotantoa monilla elintarviketeollisuuden sivutuotteilla ei olisi taloudellista käyttöä. Kierrättämällä sivutuotteita kotieläinten kautta voidaan elintarviketeollisuudelle tuottaa raaka-ainetta kohtuuhintaisilla rehuilla ja samalla pienentää sivutuotteiden aiheuttamia jätehuoltokustannuksia, jotka nostavat elintarvikkeiden hintaa. Elintarviketeollisuuden sivutuotteiden hyödyntäminen märehtijöiden ruokinnassa on varsin perusteltua: eläimet jalostavat ihmisravinnoksi kelpaamattomia sivutuotteita maidoksi ja lihaksi. Teollisuuden sivutuotteiden käyttö nautakarjan ruokinnassa on kansantalouden ja usein myös yksittäisen maatilan kannalta taloudellisesti kannattavaa.

Tämän tutkimuksen tarkoituksena oli määrittää alkoholiteollisuuden sivutuotteena syntyvien ohrarehun ja ohravalkuaisrehun tuotantovaikutus kasvavien lihanautojen ruokinnassa. Ruokintakokeella tutkittiin ohrarehun (energiarehu) ja ohravalkuaisrehun (valkuaisrehu) vaikutuksia rehun syöntiin, sonnien kasvuun sekä teurastuloksiin. Tutkimus toteutettiin MTT:n ja Altia Oyj:n yhteistyönä.

Altia Oyj:n Koskenkorvan tehtailla tärkkelys-etanoliprosessissa syntyvää ohrarehua käytetään sekä lypsylehmien että lihanautojen ruokinnassa. Ohrarehu on kuitupitoinen väkirehu, jossa on ohraan verrattuna vähemmän tärkkelystä ja enemmän kuitua. Ohrarehun tuotantovaikutusta on Suomessa aiemmin tutkittu lähinnä lypsylehmien ruokinnassa, ja ohraan verrattuna tuotantovaikutus on ollut erillisruokintakokeissa vaihteleva (Ala-Seppälä ym. 1988, Huhtanen ym. 1988). Seosrehuruokinnalla ohrarehun käyttö seoksissa lisäsi Mäntysaaren ja Khalilin (2004) tutkimuksen mukaan maito-, EKM- ja rasvatuotoksia sekä paransi energian hyväksikäyttöä, mutta laski maidon valkuaispitoisuutta. Lihanautojen ruokinnassa ohrarehua ovat tutkineet Root ja Huhtanen (1998).

Ulkomaisissa tutkimuksissa korkeilla väkirehutasoilla ruokitut lypsylehmät ovat syöneet enemmän karkearehua saadessaan väkirehuna kuitupitoista väkirehua kuin tärkkelyspitoisella väkirehulla (Thomas ym. 1986, Sutton ym. 1987, Phipps ym. 1987). Matalammilla väkirehutasoilla (väkirehua noin $40 \%$ dieetin kuiva-aineesta) vastaavaa karkearehun syönnin lisääntymistä ei ole kuitenkaan havaittu (Castle ym. 1981, Huhtanen 1987). Lihanautojen ruokinnassa dieetin väkirehutaso on suomalaisilla käytännön tiloilla usein 50 \% tai tästäkin korkeampi, joten tärkkelyksen korvaamisen kuitupitoisella väkirehulla voisi olettaa näkyvän rehun syönnin lisääntymisenä.

Altia Oyj:n Koskenkorvan tehtailla syntyy alkoholin valmistuksen sivutuotteena myös kahta nestemäistä tuotetta: tiivistettyä tärkkelysrankkia ja ohravalkuaisrehua. Tiivistettyä tärkkelysrankkia (TTR) käytetään tällä hetkellä nautojen ruokinnassa, ja sillä on tehty joitakin tuotantokokeita sekä lihanaudoilla (Joki-Tokola 1996) että lypsylehmillä (Ala-Seppälä ym. 1988, Huhtanen ja Miettinen 1992, Mäntysaari ja Khalili 2004). Ohravalkuaisrehu (OVR) on puolestaan nestemäinen sivutuote, jota tällä hetkellä käytetään valkuaisrehuna lähinnä sikojen ruokinnassa (Siljander-Rasi ym. 2002). Ohravalkuaisrehun käytöstä lihanautojen ruokinnassa ei ole olemassa aikaisempia tutkimustuloksia.

\section{Aineisto ja menetelmät}

Lihanautojen ruokintakoe toteutettiin Maa- ja elintarviketalouden tutkimuskeskuksen Pohjois-Pohjanmaan tutkimusasemalla Ruukissa. Ruokintakoe alkoi tammikuussa 2004 ja päättyi joulukuussa 2004, jolloin viimeiset koe-eläimet teurastettiin. Koe-eläimet (yhteensä $32 \mathrm{kpl}$ maitorotuisia sonneja) olivat PohjoisPohjanmaan tutkimusasemalla välikasvatettuja sonnivasikoita, jotka olivat 6-7 kk:n ikäisiä ruokintakokeen alkaessa. Kokeen alussa eläimet siirrettiin vasikkakasvatustiloista parsinavettaan, jolloin ne kytkettiin parteen. Järjestelyllä saatiin eläinkohtaisia havaintoja. Eläimet ryhmiteltiin kokeen alussa elopainon perusteella neljään blokkiin, joista ne sijoitettiin satunnaisesti eri ruokinnoille.

Koeruokinnat erosivat toisistaan väkirehu- ja valkuaisruokinnan koostumuksien osalta. Puolet koeeläimistä sai väkirehuna pelkkää ohraa ja toinen puoli väkirehuseosta, jossa puolet ohran kuiva-aineesta oli korvattu ohrarehulla. Molemmilla väkirehuruokinnoilla oli kaksi erilaista valkuaisruokintaa: 1) valkuaislisänä rypsirouhetta (500 g/eläin/pv) ja 2) valkuaislisänä ohravalkuaisrehua (2,5 kg/eläin/pv). Väkirehun tavoiteltu osuus oli 55 \% päivittäisestä kuiva-aineen syönnistä kaikilla neljällä ruokinnalla.

Koe toteutettiin seosrehuruokintana, mutta valkuaislisäykset tehtiin käsin erikseen jokaisen sonnin päivittäiseen seosrehuannokseen. Näin varmistettiin, että jokainen sonni sai halutun suuruisen valkuaislisäyksen. Sonnit saivat vapaasti seosrehua, joka sisälsi edellä mainituissa suhteissa karkearehua ja väkirehuja. Karkearehuna oli hyvälaatuinen nurmisäilörehu. Ruokinnassa huolehdittiin myös eläinten 
kivennäisaineiden sekä vitamiinien tarpeesta. Kivennäisenä käytettiin Tähkä Apekivennäistä, joka sisälsi kalsiumia 235,2 g/kg, fosforia 7,8 g/kg, magnesiumia 39,8 g/kg ja natriumia 74,4 g/kg. Kivennäistä annettiin 100 grammaa eläintä kohti päivässä. Kivennäisen lisäksi annettiin ADE-vitamiinitäydennys.

Säilörehusta tehtiin kuiva-ainemääritykset kahdesti viikossa rehuseosten laskemista varten. Lisäksi säilörehusta otettiin edustava näyte rehun siirtoajokerroittain. Näytteet yhdistettiin vastaamaan kunkin ruokintajakson (4 viikkoa) aikana syötettyä säilörehua. Ohran, rypsin, ohrarehun ja ohravalkuaisrehun analyysinäytteenä käytettiin kahden ruokintajakson aikana kerätyistä osanäytteistä yhdistettyjä kokonaisnäytteitä. Rehunäytteet lähetettiin analysoitaviksi sekä MTT:n Eläinravitsemuksen laboratorioon Jokioisille että Valio OY:n aluelaboratorioon Seinäjoelle (säilörehu ja ohra). Rehujen kemiallinen koostumus määritettiin Ahvenjärven (2000) kuvaamalla tavalla. Säilörehusta määritettiin lisäksi käymislaatu (pH, kokonaistyppi, liukoinen typpi, ammoniumtyppi, vesiliukoiset hiilihydraatit, haihtuvat rasvahapot ja maito- sekä muurahaishappo). Käymislaatua kuvaavat määritykset tehtiin Valio Oy:ssä käytössä olevalla puristenestetitraukseen pohjautuvalla laatumäärityksellä (Moisio ja Heikonen 1989). Säilörehun D-arvo määritettiin NIR-menetelmällä (Nousiainen ym. 2004).

Rehujen rehuarvot laskettiin määritettyjen analyysien ja rehutaulukosta saatujen ravintoaineiden sulavuuksien perusteella. Rehujen rehuyksikköarvot laskettiin jakamalla ME-arvo 11,7:llä (Tuori ym. 2000). Rehujen valkuaisarvot laskettiin ohutsuolesta imeytyvinä aminohappoina (OIV) (Tuori 1992). Säilörehujen syönti-indeksi määritettiin Nousiaisen ja Huhtasen (2002) kuvaamalla tavalla.

Sonnien teuraspainotavoite oli 340-350 kg. Teurastuksen yhteydessä ruhon laatu määriteltiin luokittelemalla ruhojen lihakkuus ja rasvaisuus EUROP-luokituksen mukaisesti. Ruokinnoista määritettiin ravintoaineiden näennäinen in vivo -sulavuus AIA-menetelmällä (Keulen ja Young 1977). Sulavuuskokeen kestoaika oli viisi vuorokautta, ja sen aikana kerätyistä rehu- ja sontanäytteistä analysoitiin sekundäärinen kuiva-aine, tuhka, raakavalkuainen ja NDF-kuitu Ahvenjärven (2000) kuvaamalla tavalla.

Tulosten tilastollinen käsittely tehtiin SAS-ohjelmiston varianssianalyysillä. Testauksen koemalli oli

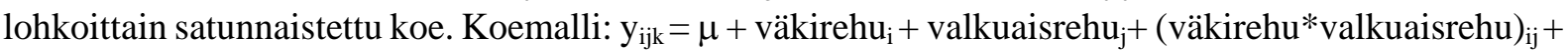
lohko $_{\mathrm{k}}+\mathrm{e}_{\mathrm{ijk} .}$ Väkirehutason ja rypsilisän välillä ei ollut tilastollisesti merkitseviä yhdysvaikutuksia $(\mathrm{p}<0.05)$. Tämä vuoksi tulokset on esitetty koetekijöittäin.

\section{Tulokset ja tulosten tarkastelu}

Rehujen kemiallinen koostumus, rehuarvot sekä säilörehun säilönnällinen laatu on esitetty Taulukossa 1. Säilörehun säilönnällinen laatu oli hyvä käymishappojen pitoisuuden sekä ammonium- ja liukoisen typen osuuksien perusteella mitattuna. Säilörehun sulavuus jäi hieman suositeltua tasoa (D-arvo 68-70) matalammaksi (D-arvo keskimäärin 67,5 kokeen aikana). Ohra oli rehuarvoltaan hyvää (Taulukko 1).

Taulukko 1. Ruokintakokeen rehujen kemiallinen koostumus, rehuarvot sekä säilörehun säilönnällinen laatu.

\begin{tabular}{|c|c|c|c|c|c|}
\hline & Säilörehu & Ohrarehu & Ohravalkuaisrehu & Ohra & Rypsi \\
\hline Kuiva-aine, g/kg & 314 & 920 & 201 & 893 & 880 \\
\hline \multicolumn{6}{|l|}{ Kuiva-aineessa, g/kg ka } \\
\hline - $\quad$ tuhka & 83 & 39 & 60 & 24 & 86 \\
\hline - $\quad$ raakavalkuainen & 168 & 146 & 383 & 136 & 355 \\
\hline - $\quad$ NDF-kuitu & 520 & 467 & 119 & 172 & 261 \\
\hline - $\quad$ raakarasva & 49 & 58 & 51 & 23 & 50 \\
\hline Ry-arvo, ry/kg ka & 0,91 & 0,99 & 1,13 & 1,14 & 1,00 \\
\hline OIV, g/kg ka & 84 & 96 & 164 & 108 & 151 \\
\hline Hehtolitrapaino, kg/hl & - & - & - & 63 & - \\
\hline D-arvo & 67,5 & - & - & - & - \\
\hline Syönti-indeksi & 99 & - & - & - & - \\
\hline $\mathrm{pH}$ & 4,16 & - & - & - & - \\
\hline \multicolumn{6}{|l|}{ Kokonaistypestä, g/kg N } \\
\hline$-\mathrm{NH}_{3}-\mathrm{N}$ & 43 & - & - & - & - \\
\hline - $\quad$ Liukoinen-N & 386 & - & - & - & - \\
\hline Maitohappo, g/kg ka & 45,50 & - & - & - & - \\
\hline Haihtuvat rasvahapot, g/kg ka & 12,00 & - & - & - & - \\
\hline Sokerit, g/kg ka & 84,08 & - & - & - & - \\
\hline
\end{tabular}


Taulukossa 2 on esitetty eläinten rehun syönti, ravintoaineiden saanti, kasvu- ja teurastulokset sekä ruokintojen näennäinen in vivo -sulavuus koetekijöittäin. Koska väkirehun (ohra tai ohra + ohrarehu) ja valkuaislisän (rypsi tai ohravalkuaisrehu) välillä ei ollut tilastollisesti merkitseviä yhdysvaikutuksia on perusteltua tarkastella tuloksia koetekijöittäin eli väkirehun ja valkuaislisän vaikutuksia erillään.

\section{Rehun syönti, ravintoaineiden ja energian saanti}

Väkirehun koostumus vaikutti tilastollisesti merkitsevästi rehun syöntiin. Ohran ja ohrarehun seosta saaneet sonnit söivät vuorokaudessa 0,6 kg ka enemmän seosrehua kuin pelkkää ohraa väkirehuna saaneet sonnit $(\mathrm{P}<0.01)$. Tulos on linjassa Thomasin ym. (1986) ja Phippsin ym. (1987) lypsylehmillä saamien tulosten kanssa, joiden mukaan korkeilla väkirehutasoilla ruokitut lypsylehmät söivät enemmän karkearehua saadessaan väkirehuna kuitupitoista väkirehua kuin tärkkelyspitoista väkirehua saadessaan.

Ravintoaineiden saantiin väkirehun koostumuksella ei tässä tutkimuksessa ollut vaikutusta. Vaikka ohrarehua saaneet sonnit kuluttivat enemmän kuiva-ainetta, niin energian saannin osalta ero koetekijöiden välillä ei kuitenkaan ollut enää tilastollisesti merkitsevä. Tämä johtui siitä, että ohrarehun energia-arvo on ohraa hieman heikompi. Näin ollen sonnit korvasivat ohrarehun heikompaa energia-arvoa lisäämällä vastaavasti seoksen syöntiä.

Valkuaislisällä ei ollut merkitsevää vaikutusta rehun syöntiin tai ravintoaineiden saantiin. Rypsilisän saaneet sonnit söivät kuitenkin hieman enemmän rehua ja niiden energian saanti oli hieman suurempi kuin ohravalkuaisrehua saaneilla sonneilla, mutta tämä ero ei ollut tilastollisesti merkitsevä.

Rehun hyväksikäyttöön väkirehun koostumuksella tai käytetyllä valkuaislisällä ei ollut tässä kokeessa vaikutusta. Lihanaudoilla saatu tulos poikkeaa siten lypsylehmillä MTT:llä Jokioisissa toteutetusta tutkimuksesta, jossa ohrarehun käyttö paransi energian hyväksikäyttöä (Mäntysaari ja Khalili 2004). Selkeimmin vaikutus oli lypsylehmillä nähtävissä ensikkoaineistossa.

\section{Dieetin sulavuus}

Ruokintojen näennäisissä in vivo -sulavuuksissa oli selkeitä eroja koetekijöiden välillä (Taulukko 2). Ohrarehun sulavuus oli huonompi kuin ohran, ja dieetin orgaanisen aineen sulavuus laski 77,3 prosentista 71,5 prosenttiin, kun puolet ohrasta korvattiin ohrarehulla $(\mathrm{P}<0.001)$. Raakavalkuaisen sulavuuteen ohrarehun käytöllä ei ollut vaikutusta, mutta rehuannoksen NDF-kuidun sulavuus heikkeni, kun rehuannokseen lisättiin ohrarehua $(\mathrm{P}<0.001)$. Tulos on yhdenmukainen Huhtasen ym. (1988) lypsylehmillä tekemän tutkimuksen tulosten kanssa.

Ohravalkuaisrehun käyttö rehuannoksessa rypsin sijasta ei vaikuttanut dieetin orgaanisen aineen tai NDF-kuidun sulavuuksiin. Sen sijaan raakavalkuaisen sulavuus laski 78,1 prosentista 75,2 prosenttiin, kun ruokinnassa käytettiin ohravalkuaisrehua rypsin sijasta $(\mathrm{P}<0.001)$.

\section{Kasvu- ja teurastulokset}

Sonnit painoivat kokeen alkaessa keskimäärin 279 kiloa. Kokeen lopussa eläinten keskimääräinen elopaino oli 675 kiloa ja teuraspaino 351 kiloa. Elo- ja teuraspainoissa ei ollut eroja koetekijöiden välillä (Taulukko 2). Tavoitellun teuraspainon saavuttamiseksi sonnit teurastettiin neljässä eri erässä lokajoulukuun 2004 aikana. Ruokintakoe alkoi sonnien olleessa 6,5 kuukauden ikäisiä ja koe kesti keskimäärin 313 vuorokautta, mikä tarkoittaa sitä, että sonnit olivat teurastettaessa noin 17 kuukauden ikäisiä.

Kasvutuloksissa ei ollut merkitseviä eroja väkirehun koostumuksen tai valkuaislisän välillä. Sonnien keskimääräinen nettokasvu kokeen aikana oli keskimäärin 698 g/pv ja koko elinajalle laskettu nettokasvu 625 g/pv. Kasvutulokset olivat kaikissa ruokintaryhmissä hyviä, sillä esimerkiksi A-Tuottajien tilaaineistossa sonnien keskimääräinen nettokasvu syntymästä teurastukseen on vuosina 2003-2004 jäänyt välille 510-530 g/pv. Parhaat tilat yltävät toki 600-700 gramman nettokasvutuloksiin. Vuonna 2004 ATuottajien paras neljännes tiloista ylsi keskimäärin 590 gramman nettokasvuun syntymästä teurastukseen (A-Tuottajat: Lihanautojen kasvuraportti Pohjois-Pohjanmaan tutkimusasemalle vuodelta 2004).

Kun koeaika jaettiin kahteen osaan, muodostui väkirehuruokintojen vaikutus eläinten kasvuun erilaiseksi kokeen eri vaiheissa (Taulukko 2). Kokeen alkupuoliskolla (eläinten elopaino alle 500 kg) ohrarehua saaneet sonnit kasvoivat hieman nopeammin kuin pelkkää ohraa saaneet eläimet (päiväkasvut 1440 g/pv vs. 1309 g/pv) $(\mathrm{P}<0.08)$. Sen sijaan kokeen jälkimmäisellä puoliskolla (eläinten elopaino yli $500 \mathrm{~kg}$ ) ohrarehua saaneiden sonnien kasvu oli heikompaa kuin pelkkää ohraa saaneilla sonneilla (päiväkasvut 1119 g/pv vs. 1217 g/pv) (P<0.05). Root ja Huhtanen (1998) päätyivät vastaavanlaiseen 
tulokseen kokeessa, jossa tutkittiin ohrarehun ja tiivistetyn tärkkelysrankin tuotantovaikutuksia kasvavilla sonneilla. Tuossakin kokeessa ohrarehua saaneet sonnit kasvoivat ohraryhmää paremmin kokeen alkupuoliskolla, mutta kasvu hidastui kokeen lopussa.

Sonnien kasvu hidastui selvästi loppukasvatuskaudella alkukasvatuskauden kasvuun verrattuna. Myös monissa aikaisemmissa tutkimuksissa koko kasvatuskauden tasaisesti rehua saaneiden nautojen kasvu on hidastunut loppuvaiheessa (Carstens ym. 1991, Ryan ym. 1993). Tämä on luonnollista, sillä nauta kasvaa sigmoidisen kasvukäyrän mukaan: kasvu kiihtyy vasikan saavuttaessa puberteetti-iän (n. 1/2v) ja kun sukukypsyys saavutetaan kasvu taas hidastuu (Allen ja Kilkenny 1984). Se, miksi kasvut heikkenivät ohrarehuryhmällä ohraryhmää enemmän loppukasvatuskaudella, ei ollut selitettävissä ohraryhmän suuremmalla syönnillä tai ravintoaineiden saannilla. Rootin ja Huhtasen (1998) tutkimuksessa ohrarehua väkirehuna saaneiden sonnien energian saannin ja tarpeen välillä oli ero kasvatuskauden loppupuoliskolla, mikä selitti heidän kokeessaan ilmenneitä kasvueroja. Tässä kokeessa loppukasvatuskauden kasvueroille ei löydy vastaavaa selittäjää. Ilmeisesti ohraryhmän eläimet pystyivät kompensoimaan ohrarehuryhmää heikomman alkuvaiheen kasvunsa loppukasvatuskaudella ja kuromaan alussa syntyneen eron umpeen.

Väkirehun koostumus ja valkuaislisä eivät vaikuttaneet teurasprosenttiin eivätkä ruhojen lihakkuuteen (Taulukko 2). Keskimääräinen teurasprosentti oli 52,1 \%, ja suurin osa ruhoista luokittui EUROP-luokkiin O- ja O, mikä on tyypillistä meillä käytössä olevalle maitorotuiselle eläinainekselle. Väkirehun koostumus ei vaikuttanut myöskään ruhojen rasvaisuuteen, mutta valkuaislisällä näytti olevan vaikutusta rasvoittumiseen: ohravalkuaisrehua saaneet sonnit luokittuivat 0,5 luokkaa korkeampaan rasvaluokkaan kuin rypsiä saaneet sonnit $(\mathrm{P}<0.05)$.

Ruhojen voimakkaampi rasvoittuminen ohravalkuaisrehuruokinnoilla näkyi myös eläimistä saaduissa teurastilityksissä (Kuva 1). Rypsiä saaneilla sonneilla teurastilitys (€/lihakilo) oli merkitsevästi suurempi kuin ohravalkuaisrehua saaneilla $(\mathrm{P}<0.05)$. Tämä ero selittyy nimenomaan tilityshintaan tehtävällä rasvavähennyksellä. Väkirehun koostumus ei sen sijaan vaikuttanut teurastilityksen suuruuteen.

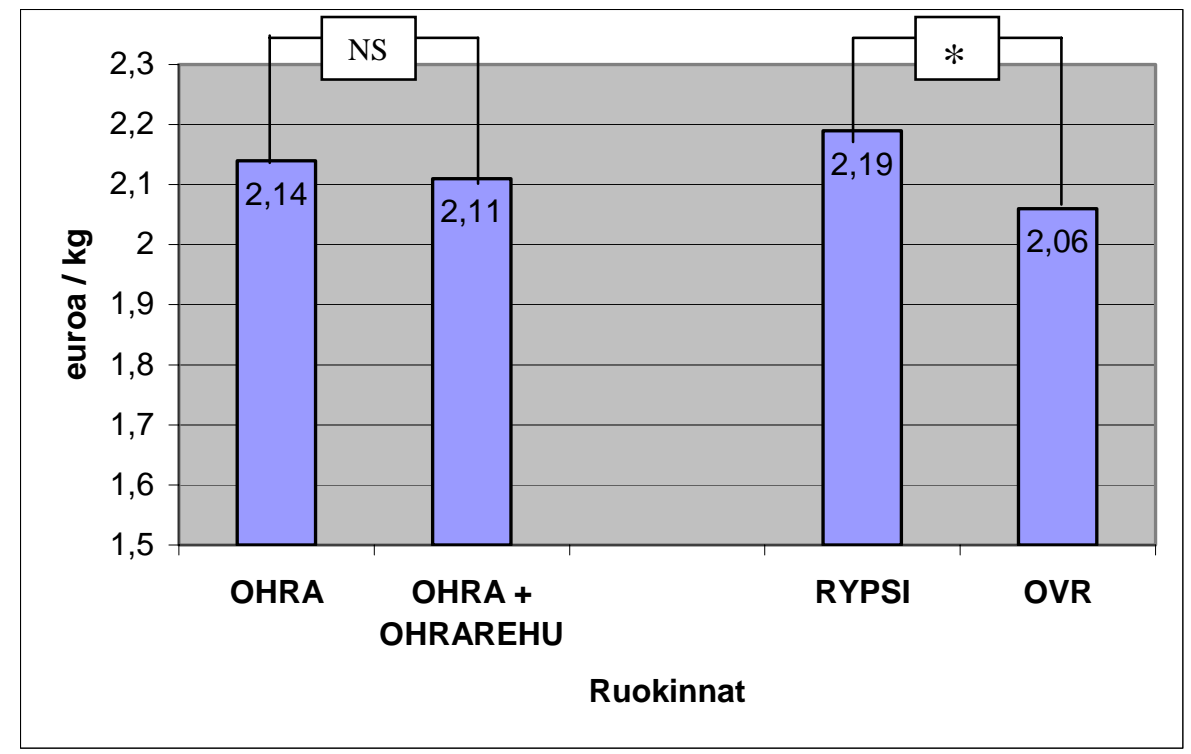

Kuva 1. Teurastili, euroa/kg (ilman arvonlisäveroa) koetekijöittäin. Tilastollinen merkitsevyys: * $=\mathrm{p}<0.05$, NS = ei tilastollista merkitsevyyttä.

\section{Johtopäätökset}

Ohrarehun käyttö väkirehussa lisäsi sonnien seosrehun syöntiä. Lisääntynyt rehun syönti ei kuitenkaan lisännyt ravintoaineiden saantia merkitsevästi eikä siten vaikuttanut kasvutuloksiin. Tämä johtui siitä, että ohrarehun sulavuus ja energia-arvo ovat ohraa hieman heikompia.

Ohrarehulla on mahdollista korvata ainakin puolet kasvavan lihanaudan väkirehuannoksesta ilman, että se vaikuttaisi negatiivisesti tuotokseen. Naudanlihantuottajan kannalta ohrarehun käyttö ruokinnassa muodostuu taloudellisesti järkeväksi, jos sen hinta suhteessa tuotantovaikutukseen on edullisempi kuin muiden käytettävissä olevien väkirehujen. Tärkkelyspitoisen väkirehun osittainen korvaaminen 
kuitupitoisella ohrarehulla on erityisen perusteltua suurilla väkirehumäärillä ruokittaessa, koska kuitupitoinen väkirehu fermentoituu pötsissä viljan tärkkelystä hitaammin. Tämä puolestaan vähentää korkeisiin väkirehumääriin liittyviä ruokinnallisia riskejä.

Rypsin korvaaminen ohravalkuaisrehulla ei vaikuttanut lihanautojen rehun syöntiin tai kasvutuloksiin. Ohravalkuaisrehudieetillä raakavalkuaisen sulavuus oli kuitenkin heikompi kuin rypsiä sisältäneellä ruokinnalla. Ohravalkuaisrehua saaneet sonnit rasvoittuivat voimakkaammin kuin rypsillä ruokitut eläimet, mikä heikensi ohravalkuaisrehulla ruokittujen sonnien taloudellista tulosta. Tulosten perusteella ohravalkuaisrehun käytölle lihanautojen ruokinnassa ei ole perusteita nykyisillä rehujen hintasuhteilla, jos ruokinnassa käytetään karkearehuna hyvälaatuista nurmisäilörehua.

\section{Kirjallisuus}

Ahvenjärvi, S., Vanhatalo, A., Huhtanen, P. \& Varvikko, T. 2000. Determination of reticulo-rumen and stomach digestion in lactating cows by omasal canal and duodenal sampling. British J. Nutr. 83: 67-77.

Ala-Seppälä, H., Huhtanen, P. \& Näsi, M. 1988. Silage intake and milk production in cows given barley fibre with or without dried distillers solubles. J. Agric. Sci. Fin. 60: 723-733.

Allen, D. \& Kilkenny, B. 1984. Planned beef production. 2nd ed. Granada, London, UK. 229 p.

Carstens, G.E., Johson, D.E., Ellenberger, M.A. \& Tatum, J.D. 1991. Physical and chemical components of the empty body during compensatory growth in beef steers. J. Anim. Sci. 69: 3251-3264.

Castle, M.E., Gill, M. \& Watson, J.N. 1981. Silage and milk production: a comparison between barley and dried sugarbeet pulp as silage supplements. Grass and Forage Sci. 36: 319-324.

Huhtanen, P. 1987. The effect of dietary inclusion of barley, unmolassed sugar beet pulp and molasses on milk production, digestibility and digesta passage in dairy cows given silage-based diet. J. Agric. Sci. Fin. 59: 101-119.

Huhtanen, P., Ala-Seppälä, H. \& Näsi, M. 1988. Response of silage intake and milk production to replacement of barley fibre derived from integrated starch-ethanol process. J. Agric. Sci. Fin. 60: 711-721.

Huhtanen, P. \& Jaakkola, S. 1993. The effects of forage preservation method and proportion of concentrate on digestion of cell wall carbohydrates and rumen digesta pool size in cattle. Grass and Forage Sci. 48: 155-165.

Huhtanen, P., Khalili, H., Nousiainen, J.I., Rinne, M., Jaakkola, S., Heikkilä, T. \& Nousiainen, J. 2002. Prediction of the relative intake potential of grass silage by dairy cows. Livest. Prod. Sci. 73: 111-130.

Huhtanen, P. \& Miettinen, H. 1992. Milk production and concentrations of blood metabolites as influenced by level of wet distiller's solubles in dairy cows receiving grass silage-based diet. Agric. Sci. Fin. 1: 279-290.

Joki-Tokola, E. 1996. Rankista ja rypsistä ei sonnien säilörehuruokinnassa ollut hyötyä. Koetoiminta ja käytäntö 53 : 52.

Keulen, J. van \& Young, B.A. 1977. Evaluation of acid-insoluble ash a marker in ruminant digestibility studies. J. Anim. Sci. 44: 282-287.

Moisio, T. \& Heikonen, M. 1989. A titration method for silage assessment. Anim. Feed Sci. Technol. 22: 341-353. Mäntysaari, P. \& Khalili, H. 2004. Ohrarehun ja rankin käyttö lypsylehmien seosrehuruokinnassa ja niiden vaikutus lehmien maidontuotantoon. Jokioinen: MTT/Eläinravitsemus. 21 s. + liitteet. (Loppuraportti Altia Oyj:lle 04/2004).

Nousiainen, J., Ahvenjärvi, S., Rinne, M., Hellämäki, M. \& Huhtanen, P. 2004. Prediction of indigestible cell wall fraction of grass silage by near infrared reflectance spectroscopy. Anim. Feed Sci. Technol. 115: 295-311.

Phipps, R.H., Sutton, J.D., Weller, R.F. \& Bines, J.A. 1987. The effects of concentrate composition and method of silage feeding on intake and performance of lactating dairy cows. J. Agric. Sci., Cambridge 109:337-343.

Root, T. \& Huhtanen, P. 1998. Barley fibre and wet distillers' solubles in the diet of growing cattle. Agric. Food Sci. Fin. 7 (3): 357-366.

Ryan, W.J., Williams, I.H. \& Moir, R.J. 1993. Compensatory growth in sheep and cattle. 1. Growth pattern and feed intake. Australian J. Agric. Res. 44: 1609-1621.

Siljander-Rasi, H., Laurinen, P. \& Partanen, K. 2002. Ohravalkuaisrehun käyttömäärä ja treoniinitäydennys lihasikojen ruokinnassa. Loppuraportti Altia Oyj:lle, Feedmix OY:lle ja Suurusrehu Oy:lle 30.11.2002. Hyvinkää: MTT/Sikatalous. $20 \mathrm{~s}$.

Sutton, J.D., Bines, J.A., Morant, S.V., Napper, D.J. \& Givens, D.I. 1987. A comparison of starchy and fibrous concentrates for milk production, energy utilization and hay intake by Friesian cows. J. Agric. Sci., Cambridge 109: 375-386.

Thomas, C., Aston, K., Daley, S.R. \& Bass, J. 1986. Milk production from silage. 4. The effect of the composition of the supplement. Anim. Prod. 42: 315-325.

Tuori, M. 1992. Rapeseed meal as a supplementary protein for dairy cows on grass silage-based diet, with the emphasis on the Nordic AAT-PBV feed protein evaluation system. Agric. Sci. Fin. 1: 369-439.

Tuori, M., Kaustell, K., Valaja, J., Aimonen, E., Saarisalo, E. \& Huhtanen, P. 2000. Rehutaulukot ja ruokintasuositukset. Helsinki: Yliopistopaino. $88 \mathrm{~s}$. 
Taulukko 2. Eläinten rehun syönti, ravintoaineiden saanti ja ruokintojen näennäinen in vivo sulavuus sekä kasvu- ja teurastulokset koetekijöittäin.

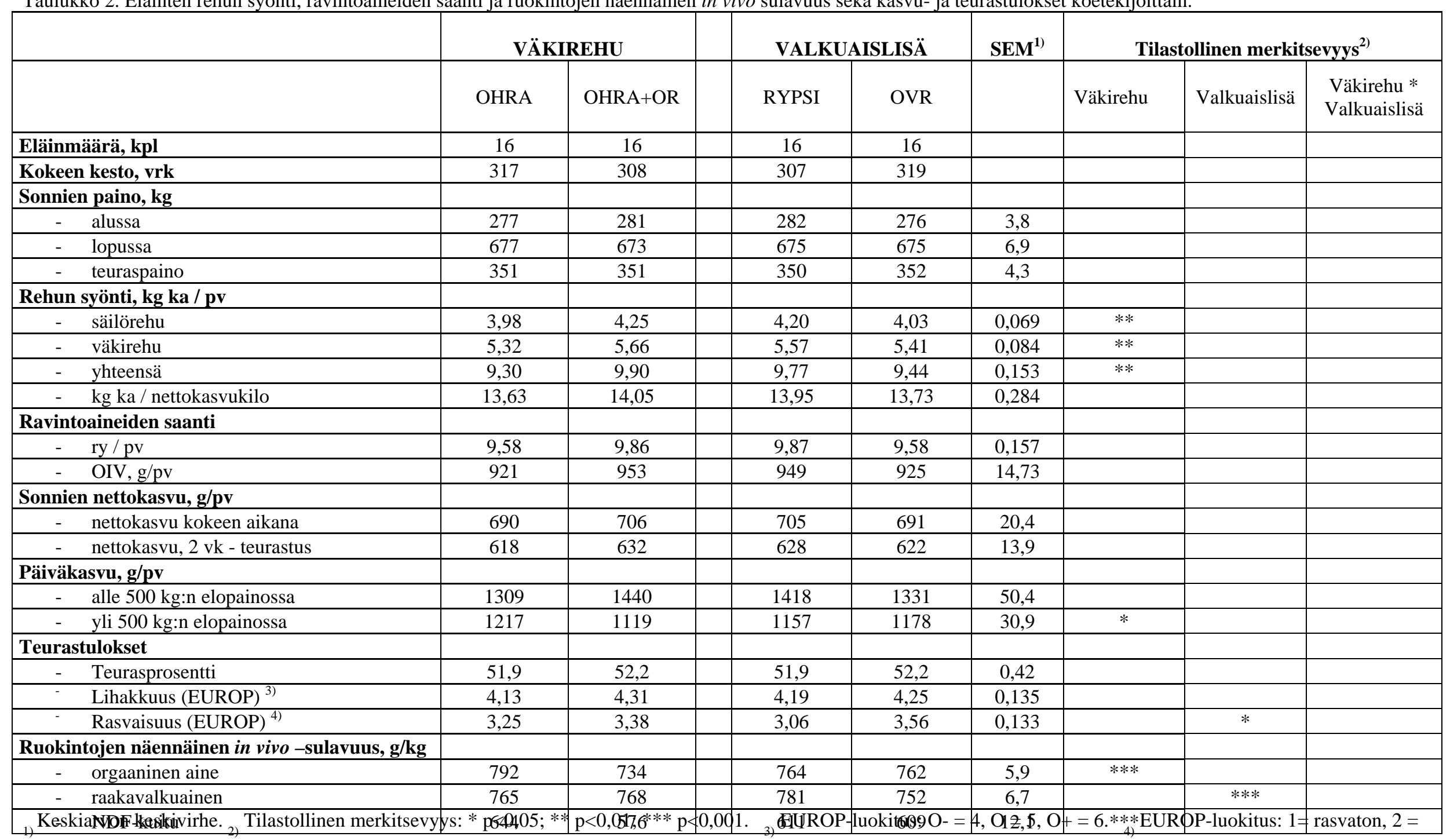

ohutrasvainen, 3 = keskirasvainen. 